\title{
Dividend Pay-Out Policy and Company Financial Performance in Kenya
}

\author{
Ogachi Daniel* \\ Doctoral School of Management and Business Administration \\ Szent Istvan University \\ PO Box 2100, Pater Karoly ut. 1. Godollo, Hungary
}

Ndege Richard

Faculty of Business and Social Sciences, JKUAT University, Nairobi, Kenya P.O Box 50353-00100 Nairobi

Gaturu Peter

Faculty of Business and Social Sciences, JKUAT University, Nairobi, Kenya

P.O Box 2229-00202 Nairobi

Zoltan Zeman

Faculty of Economics and Social Sciences, Szent Istvan University

President of the Economic Sciences Committee

P.O Box 2100, Pater Karoly, Godollo, Hungary

This research is financed by the Stipendium Hungaricum Scholarship Programme

\begin{abstract}
Dividend Payout has been a pertinent issue for both organisations and investors. Most investors prefer to invest or retain their investments in companies which declare dividends regardless of their cash flows. Companies, therefore, strive to maintain dividend payment to send positive shockwaves to investors to promote investor confidence. The objective of this study was, therefore, to ratify whether dividend payout is significant in making investment decisions. The study further sought to establish the implication dividend payment has on the financial performance of listed companies in the energy and petroleum sector in Kenya. The study used Secondary data from all the five listed companies in the energy and petroleum sector for the period 2007-2017. A descriptive design was deemed appropriate for the research. The dividend payout ratio was used as the independent variable of the study while Return on Equity and Return on Assets were the dependent variables of this study. Multiple regression analysis was used to determine relationships between the predictor and the dependent variable.
\end{abstract}

Keyword: Bankruptcy Prediction, Dividend Pay-out Ratio, Financial Performance, Ratio Analysis

DOI: $10.7176 /$ RJFA/10-10-24

Publication date:May $31^{\text {st }} 2019$

\subsection{Introduction}

Usually, the core goal of firms is to maximise the returns of investors through growing the value of shares of savings. Payment of dividends by companies is the motivation behind all firms, and they do so using two different ways; the first one being that companies pay either cash dividends to their shareholders or capital gains and secondly by retaining the bonuses and reinvesting the money on other income generating activities (Hamid, Khurram, \& Ghaffar, 2017).

In his theory on dividend payment, Gordon supports dividend payment to shareholders is one way of increasing the net worth of the firm (Press \& Review, 2010). In Contrary, researchers Miller and Scholes do not support dividend payment as they say it is not relevant. The ideology of whether to pay dividend or not has remained a mystery for most businesses today. Many companies have begun to focus their attention to this issue of dividend payment. Companies must make prudent decisions about the net profit generated from the market. They make decisions on how to share profit between the business and the shareholders who are the owners of the business. A portion of the profit is declared as dividends to shareholders while the company retains another part for reinvestment purposes. Dividend payment to shareholders has been a strategy of attracting investors to invest in the company as most investors are confident that companies which pay dividends are financially stable. The other parties also interested on dividend policies include the government for taxation purposes, the workers who would want to work in economically stable companies which are not going to collapse soon as this has a direct impact on their employment. Buyers are also interested as they always believe that the quality of products is associated with the financial stability of a company. Financially distressed institutions are deemed to compromise the quality of products and services. Lastly, the competitors will also be interested in the dividend policy so that they can remain relevant in the business environment. 
None of the studies conducted has been winning in establishing a clear idea on the influence of dividend payment and therefore, the financial performance of firms listed in Kenya. Capital Markets Authority (CMA) has not made any apparent discrepancies in terms of dividend policy in both developed and developing nations. Each company has its policy on the amount of dividend to declare to its shareholders and the amount of retained earnings for reinvestment purposes. Companies decide on the amount of bonus to pay based on the after-tax profit and is usually a portion of the net profit as they cannot spend all the net off to pay dividends. (Whitehurst, n.d.)

According to Baker, Veit, \& Powell (2001), dividend policy as a tool can be used to trigger the net worth of a firm over and above maximising returns on behalf of the shareholders using the signalling theory which is commended in policies regarding dividend payment as it is considered a form of delivering information to firm owners about company performance.

Investors always evaluate decisions made by firms and in most cases, they are keen on decisions that affect the worth of a company as this has a direct influence on the financial performance of the company as well as profitability. Therefore, Dividend involves spreading a percentage of the company's income to the investor to boost their riches is one of the ultimate destinations that support speculation by the investors. Once government obligation has been paid payment to speculators is done. Profit pay-out diminishes the measure of the held income of an organisation. The principal source of private financing for a firm is the retained income since that is the portion of the profit that is set aside for venture. In this way, there is a contention between investors and managers who have been entrusted with the authority to safeguard the interests of the shareholders because managers would need to diminish the portion of profit paid to shareholders with the goal that they can expand the held income. Then again, investors would wish to have a more prominent offer of the benefit through dividends. In a book by Firer, et al. in Yee (2017) dividend payment strategy of any association are rules utilised by an organisation in choosing the extent of the benefit that will go to the investors. The company cannot revoke the payment of dividend to shareholders once they pronounce as this turns into a financial obligation debt to the company.

Several renowned companies have collapsed even instances when the companies have declared dividends to shareholders. In 2011 Uchumi supermarket declared dividends to its shareholders but collapsed a month later. Recently Nakumatt supermarket also went under recently after several years of declaring dividends to its shareholders. Companies declare dividends to send a positive signal of financial performance to shareholders. This study, therefore, is concerned in establishing the association between dividend payment and financial performance of listed firms within the capital of Kenya securities and exchange market.

\subsection{Literature review}

The study used two approaches to literature review; a theoretical orientation or approach dealing with theories related to dividend payout and the second part consisted of the empirical examination of the literature. The study reviewed two theories; one supporting dividend pay-out while the other one was on dividend irrelevant.

\subsubsection{Gordon theory}

This theory additionally called the bird in hand theory by Myron Gordon in 1959 contended that almost all shareholders like dividends in a variety of money to capital gains. He advocated for companies to pay dividends, arguing that a bird in the hand is worth more in the bush. According to Myron, Companies that pay a dividend are regarded as best performing while those who do not pay as non-performing. The theory suggests that shareholders should invest their monies only in companies or organisations that declare dividends as it is a sign of excellent financial performance (Press \& Review, 2010). The theory also suggests that for companies to maximise their share price, they should declare significant dividends to shareholders. The cash dividend payment is a good and sure thing to do to investors as capital gains to shareholders are risky as the investors face price risk decline associated with dividend increment (Turki \& Al-khadhiri, 2013s).

\subsubsection{Miller and Modigliani Theory}

Also referred to as the MM theory. Miller and Modigliani advanced the theory in 1961. This theory was also critical in this study because it is countering the Gordon theory of dividend payout to investors. According to the theory, companies should not focus a lot on dividend payment to shareholders as this was irrelevant as it does not have any influence on the value of the firm. Investors should use other key financial performance indicators apart from dividend payment to access the financial soundness of the company. Based on the theory, the net worth of any company is affected by other factors, both internal and external, to the company apart from the dividend payment. The approach added that in an efficient market dividend declaration does not affect the shareholder's investment. The theory suggested elemental earning power and a firm's business risk as to the financial determinists of a company. This theory received critiques from many researchers the argument is that the findings of the MM theory based on the assumption of a perfect market which is hypothetical as it does not exist in the real world (Gugler \& Yurtoglu, 2003).

\subsubsection{Empirical literature}

The notion of dividend payout has been a hot topic in Kenya for discussion these days as many businesses are going under even in instances where they have declared attractive dividends to shareholders. In the view of the 
firm, Payment of dividend by companies to shareholders is a pivotal policy to reward shareholders who have entrusted their finances in the company. (Ajanthan, 2013).

Evaluating the financial performance of a company is assessing the impact of the strategies of a firm regarding financial matters. The results of such decisions are evident in the evaluation of the worth of a company or business enterprises through the assessment of the return on investment and return on assets (Zriba, 2015).

The market price of shares and therefore, the rate of dividend declared to shareholders are of interest to researchers in finding out the trend on dividend payout and financial performance of firms. Through studies, many scholarly articles have tried to demonstrate the relationship between dividend payout and stock prices and the substantial value as well. Decisions on dividend payment are essential in appreciating the concept of profit apportionment. It is a crucial concept of establishing the percentage of profit to be retained for investment purposes as we as investor appreciation through dividend payment (Primis \& Whitehurst, n.d.). Dividend payout decisions, in some instances, are less critical as they do not give any gesture on the value of the firm. Early scholars advocated for dividend payout basing their arguments that when well managed, it has a direct influence on the share price as well as the value of the firm.

A recent study by Kanwal \& Hameed (2017) discouraged cash dividend to investors as they argued that investors who receive cash dividends have no tax exemption, which increases the obligation on the investor to the government. Dividend payment has an inverse relationship with the financial performance of a company, meaning that as the firm increases dividend pay-out to investors, then the financial performance of the company decreases based on the findings from a study that was conducted by Yusuf (2015) in his research on dividend policy and performance of selected listed firms in Nigeria between 2004-2013.

A similar study by (Rashid \& Rahman, 2008) examined the relationship sandwiched between dividend payout policy and stock volatility, applying cross-sectional multivariate analysis. Variables of interest by the researcher included dividend payout ratio, debt, dividend-earning volatility, firm size and growth in assets. Findings from the study exposed a positive association flanked by stock value volatility and dividend yield. An officious avowal of this study was that the results of the study were very different from those of a similar survey conducted in a developed country meaning there is little that can be done by the managers of companies to influence stock prices, primarily through dividend policy adjustment. Since Bangladesh does not have an efficient capital market, then controlling stock price through dividend payment may be ambiguous.

Nishat \& Irfan, 2008 had exciting findings in their study on dividend payment and risk emanating from the share price of listed companies in Pakistan. The study conducted a Trend analysis for the research in the reform period (1991-2000) and during the pre-reform period (1981-1990). Findings revealed a significant influence of dividend payment policy on stock prices. Dividend payout had a considerable influence only at lower levels. Overall, the size of the form and leverage had a positive effect on price volatility of shares. On the other hand, inverse research findings established during the pre-reform period of (1981-1990), which confirmed that the size of the firm had a negative influence on share price volatility.

Yee (2017), on the other hand, conducted a study to evaluate the relationship that existed between dividend payout policy and firm performance. The objective of the study was to gauge if dividends paid to shareholders is a critical gesture for denoting firm financial performance. The research was supporting the assumption that for a company to maximise shareholders wealth, it should award higher dividend and increase the price of shares. Where, the study was very oppressive to establish underlying pillars to support dividend payment, the methodology used for the research and the sample study of the survey was missing which makes it difficult to rely on the research findings to make a general summary of the conclusions from the survey.

Turki \& Al-khadhiri (2013) researched listed non-financial firms in Saudi Arabia stock exchange. The objective of the study was to establish factors determining dividend payment. Panel data for the years 2004-2010 was used applying a regression analysis model to develop trends and behaviour of Earnings Per Share (EPS), Debt to Equity and Dividend Per Share as independent variables on the dependent variable. One hundred five companies were involved in the study. EPS and DPS were found to be the key factors which influence decisions regarding payment of dividends.

Francis, Samuel, \& Wu (2017) explored the power of the stock-price construction progression on dividend payment. The study used Secondary data divided into two phases. Years 2001-2003 and 2005-2010. The year 2004 was not included in the sample since pilot firms were not publicised all through that year. It was evident from the findings of the study that pilot companies were more likely to upsurge dividend pay-out during this program. After the termination of the program, these companies were less likely to raise dividends payment but continue to pay dividends, which increases the propensity to repurchase shares. The findings of this study were in tandem with the signalling and agency-based models, which showed noticeable results in firms with higher information asymmetry but with weaker governance. The general findings revealed that stock price volatility within the secondary financial market had a significant and enduring bearing on firms' payout policy.

Hamid et al., (2017) in their studied the dynamics of dividend payment policy and macroeconomic variables and their effect on the fluctuation of the stock price in Pakistan's financial sector for the period 2006-2014. Fixed 
and random effects analysis was conducted using panel data to identify relationships among the variable of the study. Interest fluctuations, dividend payout ratio, market value, and inflation volatility were found to have significant positive correlations with share price volatility. Interesting findings on standard impact model revealed positive correlation effects between dividend payout, interest volatility and the share price.

Whereas fixed effect model preferable and suitable good fit than a random effect model, it was indicated that the dividend payout ratio had a significant positive impact while market volatility had a significant negative impact on stock prices. Additionally, GMM results supported the fixed and random effect outcome. It was, therefore, concluded that the study considerably contributed to the dogma of dividend policy choices and appreciated the role of small and macro variables on stock value volatility within the financial sector of the country.

A study by Musiega, Alala, Douglas, Christopher, \& Robert (2013) to analyse and determine determinants of financial performance in listed non-financial companies sampled 50 companies according to the NSE report (2012). The study used purposive sampling to select a sample of 30 companies that were involved in the study. The study period was 2007-2011 using secondary data from published financial reports. The dependent variable for this study was dividend payout while the profitability of the firm, growth rate, current earnings, and liquidity ratio as the dependent variable. The moderating variable for the study was a business risk. Findings from this study showed that return on equity, current earnings and firms 'growth activities were positively correlated to dividend payout while. Introduction of business risk and firm size as moderating variables amplified the precision of significant variables from $95 \%$ to $99 \%$, which meant that they were among the significant determinants of dividend payout.

De Cesari \& Ozkan, (2015), in their study, examined the influence of managerial enticements on corporate payout policy which was a comparative study that involved 1,650 listed companies in the United Kingdom, Germany, France, Italy, the Netherlands and Spain, for the period 2002-2009. The study found lower dividend payment for executive stock option holdings and stock option deltas because of the lack of dividend protection for executive stock options in the countries involved in the study which was due to the lack of dividend protection for govt stock choices within the countries concerned in the study. The findings from the survey that govt option holdings and stock option deltas hurt the total payout, suggesting that executives were not allowed to substitute share repurchases for dividends. Also, the portion of share repurchases in total payout surges as govt option holdings and stock option deltas rise.

Baker \& Smith (2006) sampled 309 corporations exhibiting behaviour per residual dividend policy and their matched counterparts taught on how they set their dividend policies. The findings are unconcealed that the sampled corporations were a lot of doubtless than their peers to keep up a long-term dividend payout, use long earnings forecasts in setting the dividend and be unconcerned regarding the price of raising external funds. Corporations behaving like they follow a residual dividend policy usually do not profess to follow the plan. At best, the sample corporations follow a "modified" residual policy during which they fastidiously manage their payout quantitative relation and dividend trend. Though it should not be a goal of such a dividend policy, systematically low free income usually results.

Adediran \& Alade (2013) conducted a study to ascertain the relationship between dividend policy and corporate profitability, Investment and Earning Per Shares. The study used annual report and accounts of twentyfive quoted companies in Nigeria. Regression analysis was conducted using e-views software, and the findings indicated a significant positive relationship between dividend policies of organisations and profitability. Secondly, the study found a significant positive correlation between dividend policy and investments and thirdly; the study established a significant positive correlation between dividend policy and Earnings per Share. Organisations ought to make sure that they need an honest and robust dividend policy in situ as a result of it will enhance their gain and attract investments to the organisations.

\subsection{Model Summary}

The model summary of the study was as shown below; 


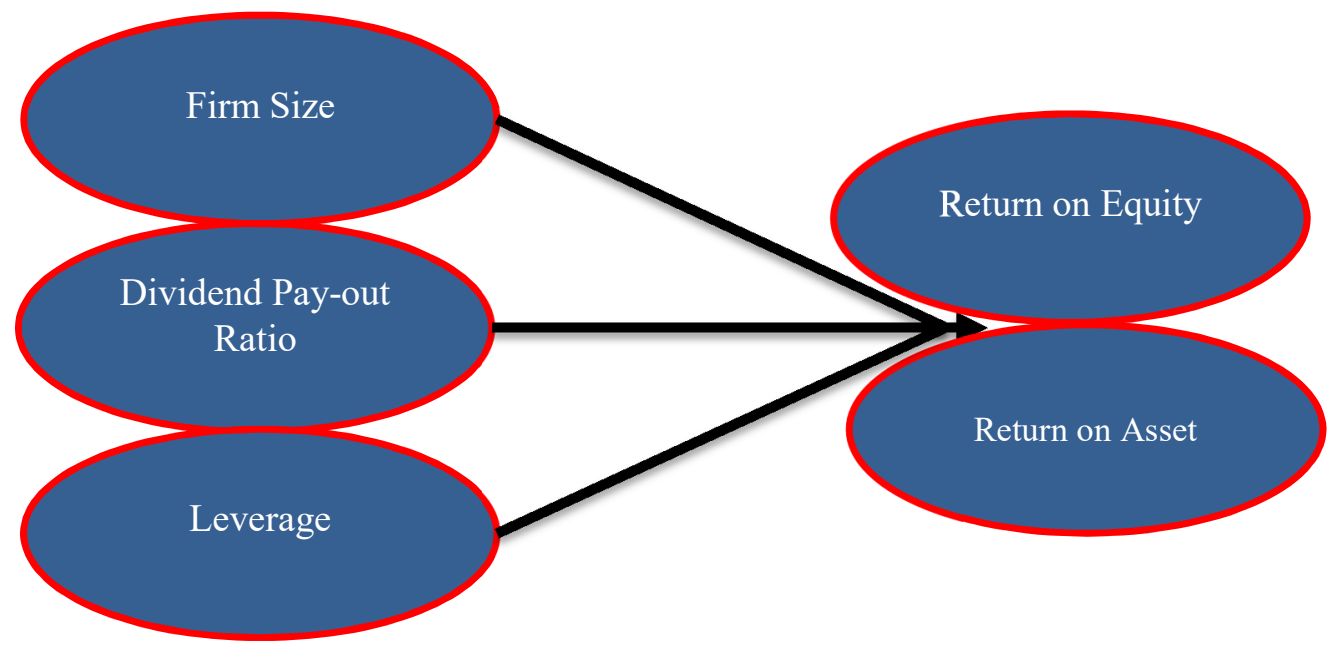

Figure 1: Author 2018

Three variable Firm size, Dividend Pay-out and Leverage were used, and their effect tested on return on investment and return on equity used as measures of financial performance.

\subsection{Methodology}

The study used Secondary data from financial statements of companies listed in the Nairobi securities and exchange market. Ten years of trend analysis for all listed companies in the energy sector for the period 20032013. Correlational analysis and multiple regression analysis were used to establish relationships among the variables. The study tested the following multiple regression model summary to determine relationships between the dependent and independent variables.

$$
\begin{array}{ll}
\text { (i) } & \mathrm{Y} 1=\alpha+\beta 1 \mathrm{X} 1+\beta 2 \mathrm{X} 2+\beta 3 \mathrm{X} 3+\varepsilon \\
\text { (ii) } & \mathrm{Y} 2=\alpha+\beta 1 \mathrm{X} 1+\boldsymbol{\beta} 2 \mathrm{X} 2+\boldsymbol{\beta 3 X} 3+\varepsilon
\end{array}
$$

Where;

$\mathrm{Y} 1=$ First Dependent Variable $-\mathrm{ROA}$ - Measure of the financial performance of the company. Used to evaluate the profitability of a company about total assets (Net income/Total assets)

$\mathrm{Y} 2=$ Second Dependent Variable - ROE - Financial performance measured expressing the amount of net income return as a percentage of shareholders equity (Net Income/Shareholder's Equity)

$\mathrm{X} 1=$ Dividend Payout ratio (Dividend per share/ Earnings per share)

$\mathrm{X} 2$ = Firm size (The Log of Total assets)

X3 = Leverage (Total debt/Total capital)

$\alpha=$ the constant term

$\beta 1, \beta 2 \& \beta 3=$ coefficient used to measure the sensitivity of the dependent variable to a unit change in the predictor variables.

$\varepsilon=$ is the error term used to capture unexplained variations in the model assumed to be normally distributed with mean zero and constant variance

\subsection{Results}

\subsubsection{Correlations}

Correlations were used to establish if there was any linear relationship between the predictor variables and the dependent. The findings from the study were as shown below; 
Table 1: Correlations

\begin{tabular}{|l|c|c|c|}
\hline & & ROA & ROE \\
\hline Leverage & Pearson Correlation & .175 & .241 \\
\hline Dividend Payout & Sig. (2-tailed) & .275 & .128 \\
\hline & Pearson Correlation & $-.542^{* *}$ & $-.412^{* *}$ \\
\hline Firm Size & Sig. (2-tailed) & .000 & .007 \\
\hline & Pearson Correlation & $-.753^{* *}$ & $-.401^{* *}$ \\
\hline & Sig. (2-tailed) & .000 & .009 \\
\hline
\end{tabular}

Using both return on equity and return on the asset as the key measures of financial performance in listed companies, firm size had a robust negative correlation $(\mathrm{r}=-0.753 \mathrm{p}$-Value 0.000$)$ with return on Assets — dividend payout, on the other hand, a strong negative correlation ( $\mathrm{r}=0.542$, P-value 0.000$)$ with ROA. Lastly, leverage had a very weak positive correlation ( $\mathrm{r}=0.175$, p-value 0.275$)$. Replacing $\mathrm{ROE}$ with ROA established a similar trend. The results revealed a negative association between Firm size and ROE ( $r=-0.401, p$-value 0.009$)$. Dividend payout ratio had a negative association with $\operatorname{ROE}(\mathrm{r}=-0.412, \mathrm{p}$-value 0.07$)$ and lastly, the results revealed a positive relationship between Leverage and $\operatorname{ROE}(\mathrm{r}=0.241$, $\mathrm{p}$-value 0.128$)$. The $\mathrm{p}$-value for dividend payout and firm size was $0.000(\mathrm{p}<0.05)$, which means that the positive and negative association that occurred was significant. It was not due to chance. The $p$-value for leverage in both the two instances was above $(p>0.05)$ threshold, which means that the difference in the association between leverage ROA and ROE was not significant. The study, therefore, concluded that firm size and dividend payout were critical indicators of the financial performance of the companies in the energy and petroleum. The relationship, however, is inverse. Investors should not, therefore, invest in companies that declare huge dividends but should consider those with higher percentages of retained earnings than the dividend.

\subsubsection{Multiple Regression Model using ROA}

Under this model, ROA is the dependent variable. The findings from the study were as shown below;

Table 2. Model Summary

\begin{tabular}{|l|r|r|r|r|}
\hline Model & \multicolumn{1}{|c|}{$\mathrm{R}$} & R Square & \multicolumn{1}{|c|}{ Adjusted R Square } & Std. Error of the Estimate \\
\hline 1 & $.818^{\mathrm{a}}$ & .670 & .643 & 1.0715445 \\
\hline
\end{tabular}

a. Predictors: (Constant), Firm Size, Leverage, Dividend Payout

The model summary $\mathrm{R}$ of $=0.818$ showed that the three-predictor variable; firm size, leverage and dividend payout accounted for $81.8 \%$ of the total variance brought about on the dependent variable. The close association also between R and R Square shows that the model of the study was reliable and could be used to make an inference, which shows a significant contribution from each of the independent variable.

Table 3. Coefficients ${ }^{\mathrm{a}}$

\begin{tabular}{|c|c|c|c|c|c|c|c|c|}
\hline \multirow{2}{*}{\multicolumn{2}{|c|}{ Model }} & \multicolumn{2}{|c|}{$\begin{array}{c}\text { Unstandardized } \\
\text { Coefficients }\end{array}$} & \multirow{2}{*}{\begin{tabular}{|c|}
$\begin{array}{c}\text { Standardized } \\
\text { Coefficients }\end{array}$ \\
Beta \\
\end{tabular}} & \multirow[b]{2}{*}{$\mathrm{T}$} & \multirow[b]{2}{*}{ Sig. } & \multicolumn{2}{|c|}{ Collinearity Statistics } \\
\hline & & $\mathrm{B}$ & Std. Error & & & & Tolerance & VIF \\
\hline \multirow[t]{4}{*}{1} & (Constant) & 30.636 & 4.662 & & 6.572 & .000 & & \\
\hline & Leverage & 3.401 & 1.302 & .248 & 2.611 & .013 & .990 & 1.010 \\
\hline & $\begin{array}{l}\text { Dividend } \\
\text { Payout }\end{array}$ & -.322 & .151 & -.229 & -2.128 & .040 & .769 & 1.301 \\
\hline & Firm Size & -2.758 & .448 & -.667 & -6.159 & .000 & .762 & 1.313 \\
\hline
\end{tabular}

a. Dependent Variable: ROA

The collinearity statistics were important to establish if our research model was affected by the collinearity of variables. The findings from the study revealed that tolerance values within the acceptable range of Tolerance should be greater than 0.2 . Therefore, the variables were not affected by collinearity in any way. Leverage was found to have a positive relationship with ROA, while dividend pay-out and firm size had inverse relationships with ROA. The findings were similar to those of (Yusuf, 2015) The model summary is; Y1 $=30.636+3.401 \mathrm{X} 1$ $-0.322 \mathrm{X} 2-2.758 \mathrm{X} 3+\varepsilon$. 


\subsubsection{Second Regression Model Using ROE}

Table 4. Model Summary

\begin{tabular}{|l|r|r|r|r|}
\hline Model & R & R Square & Adjusted R Square & Std. Error of the Estimate \\
\hline 1 & $.548^{\mathrm{a}}$ & .301 & .244 & 7.1004430 \\
\hline
\end{tabular}

a. Predictors: (Constant), Firm Size, Leverage, Dividend Payout

The model summary of $\mathrm{R}=0.548$, this showed that the three-predictor variable; firm size, leverage and dividend payout accounted for $54.8 \%$ of the total variance brought about on the dependent variable. The value of R Square and Adjusted R Square was 0.301 and 0.244 . The close range of association also between R and R Square shows that the model of the study was reliable and could be used to make an inference showing a significant contribution from each of the independent variable.

Table 5. Coefficients ${ }^{\mathrm{a}}$

\begin{tabular}{|c|c|c|c|c|c|c|c|}
\hline \multirow[b]{2}{*}{ Model } & \multicolumn{2}{|c|}{ Unstandardized Coefficients } & \multirow{2}{*}{$\frac{\text { Standardized Coefficients }}{\text { Beta }}$} & \multirow[b]{2}{*}{$\mathrm{T}$} & \multirow[b]{2}{*}{ Sig. } & \multicolumn{2}{|c|}{ Collinearity Statistics } \\
\hline & B & Std. Error & & & & Tolerance & VIF \\
\hline 1 (Constant) & 62.196 & 30.890 & & 2.013 & .051 & & \\
\hline Leverage & 17.459 & 8.630 & .280 & 2.023 & .050 & .990 & 1.010 \\
\hline Dividend Payout & -1.791 & 1.003 & -.280 & -1.785 & .082 & .769 & 1.301 \\
\hline Firm Size & -5.538 & 2.967 & -.294 & -1.867 & .070 & .762 & 1.313 \\
\hline
\end{tabular}

a. Dependent Variable: ROE

Collinearity diagnostic was conducted to ensure that the variables were not affected by highly correlated components. The findings from the study revealed tolerance values of $>0.2$. Therefore, the variables were not affected by collinearity in any way. Leverage was found to have a positive relationship with ROE with $p$-value $=$ 0.05 , meaning that the association was significant and did not happen due to chance. The regression model of the study Y1 $=62.196+17.459 \mathrm{X} 1-1.791 \mathrm{X} 2-5.538 \mathrm{X} 3+\varepsilon$. Dividend payout and firm size had inverse relationships with ROE. Their corresponding p-values were greater than 0.05 , which shows that the relationship between the variables was not significant; therefore concluding that it was due to chance. Having conflicting research findings prompted for more diagnostic analysis. Stepwise regression was, therefore, conducted to establish the significant influence of each predictor variable on the dependent's variable. The finding from the study was as shown below;

\subsubsection{Stepwise Regression (ROA)}

Table 6. Model Summary

\begin{tabular}{|l|r|r|r|r|}
\hline Model & R & R Square & Adjusted R Square & \multicolumn{1}{|c|}{ Std. Error of the Estimate } \\
\hline 1 & $.753^{\mathrm{a}}$ & .566 & .555 & 1.1956411 \\
2 & $.793^{\mathrm{b}}$ & .629 & .610 & 1.1202136 \\
3 & $.818^{\mathrm{c}}$ & .670 & .643 & 1.0715445 \\
\hline
\end{tabular}

a. Predictors: (Constant), Firm Size

b. Predictors: (Constant), Firm Size, Leverage

c. Predictors: (Constant), Firm Size, Leverage, Dividend Pay-out

Firm size accounts for $75.3 \%$ of the model summary, while a combination of firm size and leverage contributed $79.3 \%$ to the model summary. All three proctor variables contributed $81.8 \%$ to the model summary. The close association in the range between R Square and the Adjusted R Square is an indication that the findings are reliable for inferring. 
Table 7. Coefficients ${ }^{a}$

\begin{tabular}{|l|r|r|r|r|r|}
\hline \multirow{2}{*}{ Model } & \multicolumn{2}{|c|}{ Unstandardized Coefficients } & Standardized Coefficients & \\
\cline { 2 - 5 } & \multicolumn{1}{|c|}{$\mathrm{B}$} & Std. Error & Beta & $\mathrm{t}$ & Sig. \\
\hline 1 (Constant) & 35.093 & 4.612 & 7.608 & .000 \\
Firm Size & -3.112 & .436 & -.753 & -7.137 & .000 \\
\hline 2 (Constant) & 35.222 & 4.322 & 8.150 & .000 \\
Firm Size & -3.216 & .411 & -.778 & -7.831 & .000 \\
Leverage & 3.452 & 1.361 & .252 & 2.536 & .015 \\
\hline 3 (Constant) & 30.636 & 4.662 & 6.572 & .000 \\
Firm Size & -2.758 & .448 & -.667 & -6.159 & .000 \\
Leverage & 3.401 & 1.302 & .248 & 2.611 & .013 \\
Dividend Pay-out & -.322 & .151 & -.229 & -2.128 & .040 \\
\hline
\end{tabular}

a. Dependent Variable: ROA

The findings from the stepwise analysis showed a negative relationship between firm size and firm financial perform using ROA as the dependent variable. A reduction of dividend pay-out showed that form size still maintained a negative relationship, whereas leverage had a positive relationship on financial performance. Using the three-dependent variable in the stepwise analysis further revealed a similar trend in the influence of the variables on the dependent variable.

Table 8 Excluded Variables ${ }^{c}$

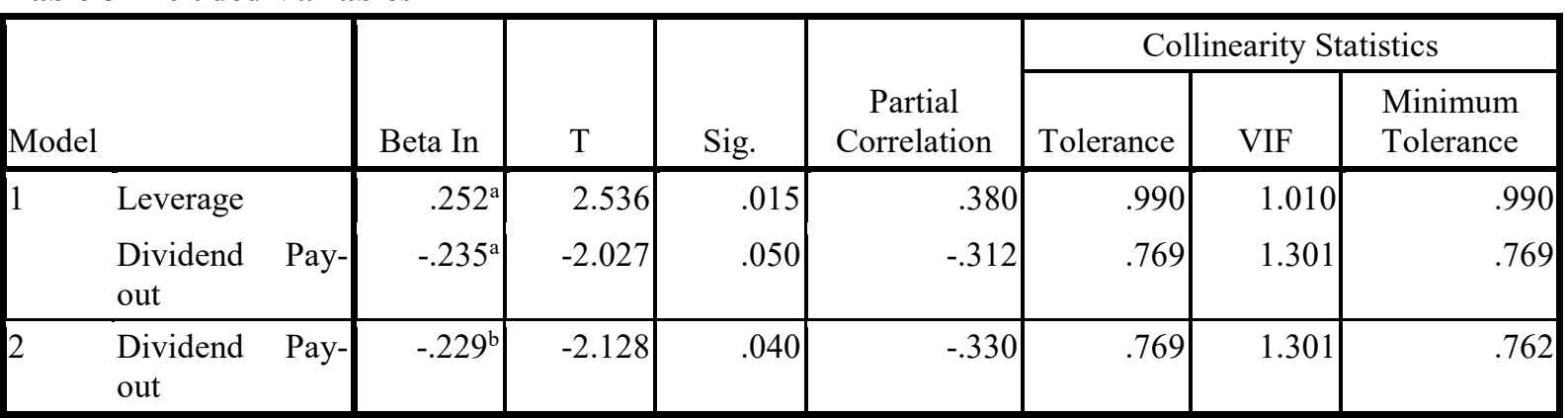

a. Predictors in the Model: (Constant), Firm Size

b. Predictors in the Model: (Constant), Firm Size, Leverage

c. Dependent Variable: ROA

The variance Inflation Factors from the findings revealed a value of $>2.0$, which is the minimum threshold. Multicollinearity was, therefore, not an issue to affect our regression model. Leverage had a positive correlation with ROA, while dividend pay-out has a negative relationship with ROA. The $\mathrm{p}<0.05$ shows that the relationship between the variables was significant and not due to chance. We, therefore, conclude that dividend pay-out has an inverse relationship with ROA.

\subsubsection{Stepwise Regression (ROE)}

A repeated stepwise analysis was conducted further with ROE as the dependent's variable. The findings are as shown below;

Table 9. Model Summary

\begin{tabular}{|l|r|r|r|r|}
\hline Model & \multicolumn{1}{|c|}{$\mathrm{R}$} & \multicolumn{1}{|c|}{ R Square } & Adjusted R Square & Std. Error of the Estimate \\
\hline 1 & $.412^{\mathrm{a}}$ & .170 & .149 & 7.5347356 \\
\hline
\end{tabular}

a. Predictors: (Constant), Dividend Pay-out

From the table above, $41.2 \%$ of the variance is brought about by the dividend payout ratio. The closeness in value between R Square and Adjusted R Square shoes that the model can best explain the variation among the variables. 
Table 10 Coefficients ${ }^{\mathrm{a}}$

\begin{tabular}{|c|c|c|c|c|c|c|c|c|}
\hline \multirow{2}{*}{\multicolumn{2}{|c|}{ Model }} & \multicolumn{2}{|c|}{$\begin{array}{c}\text { Unstandardized } \\
\text { Coefficients }\end{array}$} & \multirow{2}{*}{\begin{tabular}{|c|}
$\begin{array}{c}\text { Standardized } \\
\text { Coefficients }\end{array}$ \\
Beta \\
\end{tabular}} & \multirow[b]{2}{*}{$\mathrm{T}$} & \multirow[b]{2}{*}{ Sig. } & \multicolumn{2}{|c|}{ Collinearity Statistics } \\
\hline & & $\mathrm{B}$ & Std. Error & & & & Tolerance & VIF \\
\hline \multirow[t]{2}{*}{1} & (Constant) & 9.155 & 1.363 & & 6.716 & .000 & & \\
\hline & $\begin{array}{l}\text { Dividend Pay- } \\
\text { out }\end{array}$ & -2.639 & .933 & -.412 & -2.827 & .007 & 1.000 & 1.000 \\
\hline
\end{tabular}

a. Dependent Variable: ROE

Collinearity of the variables does not affect the model under study. The findings revealed that dividend had a negative association with ROE $\mathrm{r}=-2.639 \mathrm{p}$-value $0.007=\mathrm{p}<0.05$. We, therefore, conclude that there is a significant difference between dividend pay-out and financial performance of listed companies in the energy and petroleum sector in Kenya.

Table 11. Excluded Variables ${ }^{b}$

\begin{tabular}{|c|c|c|c|c|c|c|c|c|}
\hline \multirow{2}{*}{\multicolumn{2}{|c|}{ Model }} & \multirow[b]{2}{*}{ Beta In } & \multirow[b]{2}{*}{$\mathrm{T}$} & \multirow[b]{2}{*}{ Sig. } & \multirow[b]{2}{*}{$\begin{array}{c}\text { Partial } \\
\text { Correlation }\end{array}$} & \multicolumn{3}{|c|}{ Collinearity Statistics } \\
\hline & & & & & & Tolerance & VIF & $\begin{array}{l}\text { Minimum } \\
\text { Tolerance }\end{array}$ \\
\hline 1 & Leverage & $.255^{\mathrm{a}}$ & 1.795 & .081 & .280 & .999 & 1.001 & .999 \\
\hline & Firm Size & $-.263^{\mathrm{a}}$ & -1.616 & .114 & -.254 & .769 & 1.301 & .769 \\
\hline
\end{tabular}

a. Predictors in the Model: (Constant), Dividend Pay-out

b. Dependent Variable: ROE

Leverage had a positive correlation with financial performance, while firm size has a negative association. The corresponding $\mathrm{p}$-value was above 0.05 , which shows that the difference was not significant and may have been due to chance. The variables were, therefore, removed from the regression model.

\subsection{Conclusion}

The foremost objective of this article was to establish a relationship between dividend payment and financial performance in the Nairobi and Securities and Exchange Markets. The findings from the study revealed that Asset and dividend pay-out had an inverse relationship with financial performance while leverage had a positive relationship on financial performance which showed that the firm's financial performance is affected by the dividend payment philosophy. Consequently, the results suggest that the dividend payout ratio profoundly influenced the firm financial performance negatively. The study, therefore, concluded an inverse relationship between dividend pay-out and financial performance. Investors seeking to invest in Kenya in the energy and petroleum sector should invest in companies that declare lower dividends. Companies which offer huge bonuses should not be considered for investment as they do not reflect the actual financial position of the company.

\section{References}

Adediran, S. A., \& Alade, S. O., (2013). Dividend Policy and Corporate Performance in Nigeria. American Journal of Social And Management Sciences. https://doi.org/10.5251/ajsms.2013.4.2.71.77

Ajanthan, A., (2013). Corporate Governance and Dividend Policy: a Study of Listed Hotels and Restaurant Companies in Sri Lanka. International Journal of Scientific \& Research Publications, 3(12), 98-114.

Baker, H. K., \& Smith, D. M. (2006). In search of a residual dividend policy. Review of Financial Economics. https://doi.org/10.1016/j.rfe.2004.10.002

Baker, H. K., Veit, E. T., \& Powell, G. E. (2001). Factors Influencing Dividend Policy Decisions of Nasdaq Firms. The Financial Review, 36(3), 19-38. https://doi.org/10.1111/j.1540-6288.2001.tb00018.x

De Cesari, A., \& Ozkan, N. (2015). Executive incentives and payout policy: Empirical evidence from Europe. Journal of Banking and Finance. https://doi.org/10.1016/j.jbankfin.2014.12.011

Francis, B. B., Samuel, G., \& Wu, Q. (2017). The Impact of Financial Markets on Payout Policy: Evidence from Short Selling. Ssrn. https://doi.org/10.2139/ssrn.3038300

Gugler, K., \& Yurtoglu, B. B., (2003). Corporate governance and dividend payout policy in Germany. European Economic Review, 47(4), 731-758. https://doi.org/10.1016/S0014-2921(02)00291-X

Hamid, K., Khurram, M. U., \& Ghaffar, W. (2017). Juxtaposition of Micro and Macro Dynamics of Dividend Policy on Stock Price Volatility in Financial Sector of Pakistan: (Comparative Analysis through Common, Fixed, Random and GMM Effect). Journal of Accounting Finance and Auditing Studies, 3(1).

Kanwal, M., \& Hameed, S., (2017). The Relationship between Dividend Payout And Firm Financial Performance. 
Research in Business and Management, 4(1), 5. https://doi.org/10.5296/rbm.v4i1.10784

Musiega, M. G., Alala, O. B., Douglas, M., Christopher, M. O., \& Robert, E. (2013). Determinants Of Dividend Payout Policy Among Non-Financial Firms On Nairobi Securities Exchange, Kenya. International Journal of Scientific \& Technology Research.

Nishat, M., \& Irfan, C. M., (2008). Dividend Policy and Stock Price Volatility in Pakistan. The Pakistan Development Review, 4(1), 175-188. https://doi.org/10.1080/096031096334402

Onali, E., (2014). Moral Hazard, Dividends, and Risk in Banks. Journal of Business Finance and Accounting. https://doi.org/10.1111/jbfa.12057

Press, T. M. I. T., \& Review, T. (2010). Dividends, Earnings, and Stock Prices, 41(2), 99-105.

Primis, H., \& Whitehurst, D. (n.d.). Finance Fundamentals of Corporate Finance. Retrieved from http://www.untag-smd.ac.id/files/Perpustakaan_Digital_1/corporate finance Fundamentals of Corporate Finance, 6th Ed - Vol I.\%5B2002.ISBN0072553073\%5D.pdf

Rashid, A., \& Rahman, A. Z. M. A., (2008). Dividend Policy and Stock Price Volatility: Evidence from Bangladesh. The Journal of Applied Business and Economics, 8(4), 71-81. Retrieved from http://search.proquest.com/docview/218717004? accountid $=27540$

Turki, S. F. A., \& Al-khadhiri, A. (2013). Determination of dividend policy: the evidence from Saudi Arabia. International Journal of Business and Social Science, 4(1), 181-192. https://doi.org/10.30845/ijbss

Whitehurst, D. (n.d.). abc.

Yee, T. C., (2017). Dividend Pay-out Policy and Firm Performance. Journal of Arts \& Social Sciences, 1(1), 4252.

Yusuf, B. R., (2015). Dividend payout ratio and performance of deposit money banks in Nigeria. International Journal of Advances in Management and Economics, 4(6), 98-105.

Zriba, H., (2015). Journal of Humanities and Cultural Studies, 2(2). 